\title{
ANALISIS PENANGANAN POLITIK UANG DITINJAU DARI UNDANG-UNDANG PILKADA
}

\author{
I Wayan Febrianto, Ida Ayu Putu Widiati, Luh Putu Suryani \\ Fakultas Ilmu Hukum Universitas Warmadewa, Denpasar - Bali, Indonesia \\ ipebrianto@yahoo.com, idaayuwidiati.fhjurnal@gmail.com, suryani.fhwjurnal@gmail.com
}

\begin{abstract}
Abstrak
Money politic atau politik uang dalam Pilkada akhir-akhir ini menjadi salah satu hal yang mendapat perhatian publik. Politik uang dilakukan untuk memperoleh suara yang banyak dan menguasai suara dalam Pilkada. Politik uang dapat memberikan dampak negatif bagi calon peserta Pilkada. Penelitian ini dilakukan dengan tujuan mendeskripsikan bagaimana pengaturan pelarangan politik uang dalam pilkada dan apa sanksi bagi calon peserta Pilkada yang melakukan politik uang. Penelitian ini dilakukan dengan menggunakan metode hukum normatif. Penelitian ini menunjukkan bahwa pengaturan tentang larangan politik uang dalam Pilkada diatur dalam Undang-Undang Nomor 10 Tahun 2016 tentang Pilkada. Selain itu, sanksi bagi calon peserta Pilkada yang melakukan politik uang diatur dalam Undang-Undang Nomor 10 Tahun 2016 sebagaimana telah diubah dari Undang-Undang Nomor 8 Tahun 2015 tentang Pilkada. Calon peserta Pilkada yang kedapatan melakukan politik uang akan dikenakan sanksi kurungan minimal 36 bulan dan maksimal 72 bulan, serta denda minimal Rp. 200.000.000 (dua ratus juta rupiah) dan maksimal Rp. 1.000.000.000 (satu miliar rupiah).
\end{abstract}

Kata Kunci: Pilkada; Politik Uang; Sanksi

\begin{abstract}
Money politics in the regional elections lately has become one of the things that have attracted public attention. Money politics is carried out to get a lot of votes and control the votes in the regional elections. Money politics can have a negative impact on prospective regional election participants. This research was conducted with the aim of describing the regulation of money politics prohibition in the regional elections and the sanctions for regional election candidate participants who commit money politics. This research was conducted using the normative legal method. This research showed that the regulation regarding the prohibition of money politics in regional elections is regulated in Law Number 10 of 2016 concerning the regional elections. In addition, the sanctions for candidates for regional elections who commit money politics are regulated in Law Number 10 of 2016 as amended from Law Number 8 of 2015 concerning the regional elections. Candidates for regional elections who are caught engaging in money politics will be subject to a minimum of 36 months imprisonment and a maximum of 72 months, as well as a minimum fine of IDR 200,000,000 (two hundred million rupiah) and a maximum of IDR. 1,000,000,000 (one billion rupiah).
\end{abstract}

Keywords: Money Politics; Regional Election; Sanction

\section{PENDAHULUAN}

Keberadaan negara demokrasi di Indonesia diatur dalam Pembukaan UUD 1945. Beberapa ketentuan tersebut dapat secara langsung menampakkan karakter demokratisnya, namun ada pula yang masih netral, sehingga sifat demokratisnya masih sangat tergantung pada kebijakan politik yang ada. Dalam Pembukaan ayat 4 UUD 1945 dan ayat 4 Pancasila dirumuskan bahwa "Demokrasi dipimpin oleh kearifan dalam musyawarah atau representasi". Dengan demikian, demokrasi Pancasila adalah demokrasi musyawarah.

Demokrasi yang baik didasarkan pada prinsip jujur dan adil. Namun dalam implementasinya dalam demokrasi seringkali terdapat penyimpangan, salah satunya adalah terjadinya politik uang dalam Pilkada (Khairazi, 2015; Seran, 2016). Seorang calon peserta yang ingin berpengaruh dalam Pilkada dengan memberikan imbalan materi dalam upaya memperoleh kekuasaan sebagai pemegang suara proses politik baik milik pribadi dilakukan dengan memberikan imbalan dikenal dengan sebutan 
politik uang atau money politic. Secara harfiah dapat diartikan bahwa money politik atau politik uang adalah proses tindakan jual beli suara dalam proses perolehan suara masyarakat dengan memberikan imbalan. Proses pilkada akan berjalan dengan baik ketika semua calon peserta Pilkada jujur dan tidak melakukan money politik. Keberadaan money politik dapat menjadi isu yang aktivitas Pilkada (Kumolo, 2015).

Money politic atau politik uang dalam Pilkada akhir-akhir ini menjadi salah satu hal yang mendapat perhatian publik. Politik uang dilakukan untuk memperoleh suara yang banyak dan menguasai suara dalam Pilkada (hariyani, 2015; Marsudi \& Sunarso, 2019; Nabila, Prananingtyas, \& Azhar, 2020). Keadaan ini menjadikan terjadinya permasalahan di masyarakat, dimana kepercayaan masyarakat akan politik menjadi melemah. Terlebih lagi timbul keadaan dimana banyak masyarakat yang tidak berpartisipasi aktif dan cenderung pasif dalam politik. Banyak masyarakat yang menganggap bahwa yang berkuasa bukanlah dari pengetahuan yang dimiliki tetapi lebih pada kepemilikan uang. Hal ini didukung oleh keadaan di masyarakat dimana segala sesuatu dalam proses pemilihan melibatkan materi. Padahal kenyataannya menunjukkan bahwa seharusnya suara pemilih di dapat dengan menunjukkan visi dan misi bukan dengan pamer materi. Dilihat dari sisi hukum formal aktivitas politik uang dilarang dan melanggar aturan yang ada. Hal ini tertuang dalam UndangUndang Nomor 10 Tahun 2016 yang menyebutkan bahwa calon peserta Pilkada dilarang menjanjikan atau memberikan uang atau materi lainnya selama proses politik berlangsung.

Pilkada yang baik secara konstitusional merupakan salah satu prasyarat terciptanya kehidupan demokrasi yang ideal di suatu negara (Gaffar, 2004). Pelaksanaan proses Pilkada yang baik membutuhkan komitmen dari seluruh pemangku kepentingan yang terlibat dalam proses pemilu seperti penyelenggara pemilu (KPU Daerah, Panwaslu), calon atau peserta Pilkada serta semua pihak yang terlibat di dalamnya. Proses pemilihan yang baik dilandaskan berdasarkan prinsip Luber Judul (langsung, umum, bebas, jujur dan adil). Prinsip politik ini diharapkan dapat memberikan pemimpin yang baik dan bertanggung jawab serta memiliki legitimasi yang tinggi untuk menjalankan roda pemerintahan. Dalam model Schumpeterian (prosedural) satu-satunya sumber legitimasi adalah hasil proses Pilkada (Aspinall \& Sukmajati, 2015).

Namun dalam prakteknya pelaksanaan pilkada yang baik dan berdasarkan luber jurdil ini sangat sulit. Hal ini terjadi karena dipengaruhi oleh faktor kurangnya keterlibatan para pemangku kepentingan yang terlibat dalam penyelenggaraan pemilu yang berujung pada pelanggaran yang dilakukan calon peserta dan juga tim suksesnya. Hal ini akan berdampak negatif dan mempengaruhi jalannya roda kehidupan politik dan pemerintahan. Tatanan kehidupan politik akan berubah dan memberikan warna berbeda terhadap pengambilan keputusan publik. Pimpinan yang baik dan memiliki dedikasi akan selalu mengutamakan kepentingan masyarakat. Segala keputusan dan kebijakan yang ada akan berlandaskan pada hal- hal yang diperlukan masyarakat, bukan hal-hal yang diinginkan oleh pemimpin. Untuk itu maka dalam proses pemilihan harusnya rakyat memilih berdasarkan legitimasi yang dimiliki calon peserta, bukan atas pemberian atau janji-janji materi yang diutarakan. Selain berdampak pada harapan kedepan akan kemajuan negara tindakan politik uang ini juga akan mengancam keberadaan sistem demokrasi yang ada.

Politik uang memberikan pengaruh yang tidak baik karena akan berdampak dan dapat merendahkan martabat rakyat. Politik uang juga merupakan suatu jebakan yang dapat menyebabkan terperangkapnya masyarakat akan kehidupannya selama satu periode kepemimpinan. Hal ini karena pemimpin yang tidak memiliki dedikasi untuk rakyat tidak akan mampu memberikan pengabdian pada rakyat, tidak mampu menjalankan agenda perubahan yang telah dicanangkan serta mungkin tidak bisa menjalankan visi dan misi yang telah diutarakan selama proses pemilihan atau kampanye berlangsung. Jadi dapat dibayangkan selama 5 tahun rakyat aka nada di bawah bayang-bayang kebutaan politik dan hal ini yang memicu terjadinya tindakan-tindakan melanggar hukum akibat rendahnya pemahaman akan politik yang berlangsung. Kenyataannya masih banyak masyarakat yang belum paham akan prinsip demokrasi yang ada di Indonesia. Dalam perpolitikan terkadang masyarakat hanya menjadi wayang dan tidak mampu menetapkan pilihan berdasarkan hati nuraninya. Masyarakat cenderung terpengaruh oleh ajakan dan suruhan dari pihak-pihak yang sebenarnya tidak memiliki wewenang secara hukum untuk mengarahkan masyarakat dalam hal pemilihan (Hertanto, 2006). 
Dikutip dari Kompas.com (2019) memberitakan bahwa terjadi 6 Kasus Politik Uang Jelang Pilkada. Dari artikel dalam Kompas.com disebutkan bahwa terjadi beberapa kasus dalam proses Pilkada, diantaranya adalah sebagai berikut:

1. Bawaslu Kota Pekanbaru melakukan operasi tangkap tangan dan menyita barang bukti Ratusan Juta Rupiah

Di Dalam operasi tangkap tangan (OTT) yang dilakukan oleh Bawaslu di Pekanbaru pada Selasa (16/4/2019) jam 13.30 WIB berhasil melakukan penangkapan terhadap empat orang terduga melakukan politik uang. Dari tangan pelaku diamankan Uang sebesar Rp. 506.400.000, dimana penangkapan ini terjadi karena adanya laporan dari masyarakat tentang pelaku yang diduga akan melakukan serangan fajar pada masa tenang kampanye Pilkada tahun 2019.

2. Polres Nias Tangkap Caleg Gerindra

Polres Nias juga melakukan OTT terhadap seorang calon anggota legislatif DPRD Sumatera Utara (Sumut) dari Partai Gerindra yang juga merupakan ketua tim pemenangan calon presiden nomor urut 02 di Pulau Nias berinisial DRG, Selasa (16/4/2019). Selain DRG, polisi juga menangkap tiga orang lain, yaitu MH (37), KT (18), dan FL. Berdasarkan keterangan polisi, DRG diamankan bersama tiga orang tim suksesnya di posko pemenangan relawan di Jalan Sirao, Kelurahan Pasar, Gunungsitoli, Kota Gunungsitoli, Sumatera Utara. Selain itu, polisi juga mengamankan sejumlah barang bukti berupa uang Rp 60 juta dan sejumlah dokumen lain. Kapolres Nias AKBP Deni Kurniawan mengatakan, penangkapan DRG dan tiga orang itu diduga terkait politik uang. "Ada aktivitas yang bukan biasanya terjadi di posko tersebut," kata Deni di Mapolres Nias, Selasa. Tiga pelaku mengaku akan membagikan uang tersebut kepada 2.400 orang.

3. Caleg dan Tim Sukses diamankan terkait Money Politic di Karo

Polres Karo berhasil melakukan operasi tangkap tangan (OTT) di Karo, yaitu dengan menangkap tiga orang tim sukses dan dua caleg yang terduga melakukan politik uang. Dari ketiga orang yang ditangkap adalah Tim Sukses dari calon partai Gerindra di Karo. Pada saat diamankan pelaku membawa uang Rp. 11.700 .000 beserta tiga kartu nama dengan inisial TJG caleg DPR, IM caleg DPRD provinsi, dan KS caleg DPRD kabupaten/kota.

4. Caleg Golkar tertangkap tangan sedang melakukan Politik Uang

Caleg Golkar di Sulbar berinisial HSL tertangkap telah melakukan politik uang dengan membagikan uang di rumah salah satu masyarakat di di Desa Sumarrang, Polewali Mandar, Sulawesi Barat, Senin (15/4/2019). Kasus HSL kini sedang ditangani Bawaslu Polewali Mandar. Dari tangan pelaku diamankan sejumlah barang bukti dan didapati bahwa pelaku sedang membagikan uangs ebesar Rp. 200.000 untuk setiap anggota keluarga yang telah ditetapkan sebagai pemilih.

5. Politisi Gerindra jadi tersangka Politik Uang

Wakil Bupati pun menjadi tersangka atas dugaan politik uang yang telah dilakukan. Kasus ini terjadi di Kabupaten Padang Lawas Utara, Sumatera Utara, Masdalipa Siregar. Dalam penangkapan tersebut, polisi mengamankan 87 lembar amplop berisi uang Rp 43,4 juta.

6. 80 Amplop Diamankan

Dari posko pemenangan M. Taufik yang berlokasi di Warakas, pada Senin (15/4/2019) diamankan 80 amplop yang diduga sebagai sarana politik uang dalam upaya memperoleh suara dalam pemilihan. Dari tangan pelaku ditemukan bahwa setiap amplop berisi uang tunai sebesar Rp. 500.000.

Berdasarkan latar belakang di atas, penelitian ini dilakukan dengan tujuan mendeskripsikan bagaimana pengaturan pelarangan politik uang dalam pilkada dan apa sanksi bagi calon peserta Pilkada yang melakukan politik uang.

\section{METODE PENELITIAN}

Penelitian ini merupakan penelitian hukum normatif yaitu dianalisis dari peraturan perundangundangan yang ada (Fajar \& Achmad, 2010) yang selanjutnya dianalisis dengan pendekatan statutori dan konseptual. Bahan hukum yang digunakan merupakan bahan hukum primer dan sekunder dalam menyelesaikan fenomena dalam rumusan masalah. Cara pengumpulan bahan hukum dilakukan dengan cara mencatat, mengutip, meringkas, kemudian mereview dokumen berupa peraturan perundang-undangan, literatur, majalah, surat kabar, dan pasal lain yang berkaitan dengan penanganan penyelenggaraan politik uang. yang diatur dalam UU Pilkada. Bahan hukum dianalisis secara logika hukum deduktif yang kemudian dianalisis secara sistematis. 


\section{HASIL DAN PEMBAHASAN}

\section{Pengaturan Pelarangan Politik Uang dalam Pilkada}

Demokrasi menjadikan rakyat memiliki posisi tertinggi untuk menentukan pilihan dalam proses Pilkada. Pada dasarnya pemerintah yang baik adalah oleh rakyat, dari rakyat dan untuk rakyat. Hal ini mengindikasikan bahwa ketika masyarakat dapat melakukan pemilihan yang selektif maka pemerintahan akan berjalan dengan baik dan sesuai dengan tatanan kehidupan politik yang bersih. Dalam proses pemilihan inilah kunci awal dari berjalan tidaknya sistem demokrasi. Pada dasarnya prinsip demokrasi dalam suatu aktivitas pemilihan umum atau Pilkada adalah berlandaskan pada prinsip Luber Jurdil yaitu jujur, bebas, rahasia dan adil. Oleh karena itu tindakan mempengaruhi pemilih untuk memilih suatu calon tertentu bertentangan dengan aturan perundang-undangan yang ada (Panjaitan, 2013).

Proses pemilihan langsung yang dilakukan oleh rakyat akan sangat mempengaruhi menang atau tidaknya calon peserta Pilkada. Untuk itu maka partisipasi masyarakat sangat penting dan menjadi penentu kedudukan calon peserta Pilkada dalam menentukan apakah mendapat kursi atau tidak. Dalam prose pemilihan ada beberapa standar atau kriteria yang harus dipenuhi untuk menjadi calon peserta Pilkada. Oleh karena peserta pemilihan lebih dari satu maka akan menyebabkan terjadinya persaingan dalam proses pemilihan. Hal inilah yang memicu terjadinya penyimpangan-penyimpangan hukum dalam proses politik. Salah satu bentuknya adalah dengan munculnya politik uang atau Money politic.

Politik uang adalah suatu gangguan dalam proses politik dimana peserta atau kader atau tim sukses serta pihak-pihak pendukung calon melakukan tindakan yang melanggar hukum dengan memberikan imbalan atau materi dan atau imbalan dalam bentuk lainnya untuk mempengaruhi suara yang akan diberikan oleh pemilih. Politik uang tidaklah dibenarkan secara hukum. Hal ini akan menyebabkan kekacauan pada paradigma hukum dan politik di Indonesia. Prinsip demokrasi tidak dapat dijalankan dengan baik. Kebebasan dalam menentukan pilihan dengan berdasarkan hati nurani sendiri buka lagi menjadi prioritas utama. Timbul paradigma baru di benak masyarakat, dimana yang akan berkuasa adalah yang memiliki uang. Hal ini akan berpengaruh pada strukturisasi pemerintahan. Sebagai pengemban aspirasi masyarakat pemimpin seharusnya yang mampu mewakili suara hati masyarakat. Apabila dari awal sudah tidak dilakukan pemilihan dengan berdasarkan pilihan masyarakat itu sendiri bukankah keputusan akhirnya juga pasti tidak sesuai dengan yang diharapkan masyarakat. Untuk itu politik uang kini menjadi menjadi perhatian pemerintah dan diharapkan dapat diminimalisir keberadaannya dalam pemilihan baik itu dalam Pemilu maupun dalam Pilkada.

Terkait dengan keberadaan politik uang ketika proses pemilihan berlangsung maka dikeluarkanlah Undang-Undang Nomor 10 Tahun 2016 yang mengatur tentang larangan kegiatan politik uang. Dalam peraturan tersebut ditegaskan bahwa setiap calon peserta Pilkada dilarang untuk menjanjikan atau memberikan imbalan baik dalam bentuk uang maupun barang yang akan mempengaruhi pemilih. Dalam Undang-Undang tersebut juga mengatur tentang tindakan apa saja yang tidak boleh dilakukan oleh calon peserta terhadap pemilih. Perolehan suara harusnya berlandaskan pada visi dan misi dari calon peserta Pilkada bukan dari imbalan yang dijanjikan. Untuk itu maka tindakan politik uang dilarang dalam proses pemilihan dan kampanye di Pilkada.

\section{Sanksi bagi Calon Peserta Pilkada yang Melakukan Politik Uang}

Salah satu bentuk pelanggaran terhadap proses pemilihan umum yang sering terjadi adalah adanya kasus politik uang dalam proses kampanye. Politik uang dapat dilakukan oleh berbagai pihak baik itu calon peserta Pilkada kader, tim sukses dan pihak-pihak lainnya yang terlibat dalam proses pemilihan. Adapun bentuk dari politik uang adalah dengan memberikan imbalan berupa uang atau materi serta dapat juga berupa barang kebutuhan sehari-hari seperti sembako untuk mendapatkan simpati masyarakat dan mengharapkan masyarakat akan memberikan suaranya untuk calon peserta tersebut. Hal ini telah menjadi salah satu paradigma baru dalam kehidupan hukum, di mana mendekati proses pemilihan maka akan terdapat banyak isu-isu keberadaan politik uang tersebut.

Keberadaan politik uang di tengah-tengah masyarakat sebenarnya akan memberikan dampak yang tidak baik terhadap politik dan sistem demokrasi di Indonesia. Akibat keberlanjutan yang berlangsung jangka panjang, kini masyarakat mulai tidak mempercayai politik. Bagi sebagian masyarakat yang akan berkuasa dalam politik adalah mereka yang memiliki uang. Jadi intinya kekuasaan dalam politik itu akan terjadi apabila memiliki uang. Pemikiran masyarakat yang seperti ini 
sebenarnya salah dan keliru. Apabila ada sinergis antara masyarakat dengan sistem demokrasi maka roda pemerintahan akan berjalan dengan baik dan kehidupan masyarakat akan berada pada tatanan kehidupan yang lebih baik.

Politik uang adalah salah satu hal yang tidak dibenarkan secara hukum. Politik uang dapat memberikan pengaruh negatif pada masyarakat dan calon peserta Pilkada itu sendiri. Masyarakat kemungkinan akan menyesal apabila nantinya kebijakan dan program kerja tidak berjalan sesuai dengan yang diharapkan. Sedangkan peserta calon Pilkada akan memiliki resiko akan dikeluarkan dari hak kepesertaannya dalam Pilkada apabila diketahui melakukan pelanggaran politik uang. Dalam upaya mengatasi masalah ini Pemerintah telah mengatur sanksi yang tegas bagi calon yang melakukan pelanggaran dalam melakukan politik uang.

Terkait dengan sanksi bagi calon peserta Pilkada yang melakukan Politik Uang terdapat dalam berbagai aturan yaitu di Undang-Undang Nomor 10 Tahun 2016 dan KUHP. Undang-Undang Nomor 10 tahun 2016 di Pasal 187A dijelaskan bahwa "Barang siapa dengan sengaja melakukan perbuatan melawan hukum dengan menjanjikan atau memberikan uang atau materi lainnya dengan imbalan warga negara Indonesia baik secara langsung maupun tidak langsung untuk mempengaruhi pemilih agar tidak menggunakan hak pilihnya, menggunakan hak pilihnya dengan cara tertentu sehingga pemungutan suara menjadi tidak sah, memilih calon tertentu, atau tidak memilih calon tertentu sebagaimana dimaksud dalam Pasal 73 ayat (4), dipidana dengan pidana penjara paling singkat 36 (tiga puluh enam) bulan dan paling lama 72 (tujuh puluh dua) bulan dan denda paling sedikit Rp 200.000.000 (dua) ratus juta rupiah) dan maksimal Rp. 1.000.000.000 (satu miliar rupiah). Sanksi yang sama diberlakukan bagi pemilih yang dengan sengaja melakukan perbuatan melawan hukum dan mendapatkan hadiah atau janji sebagaimana dimaksud pada ayat (1)".

Sedangkan dalam KUHP BAB V tentang penyertaan Tindak pidana tepatnya di Pasal 55 dijelaskan bahwa (1) Dipidana sebagai pelaku tindak pidana: (a) mereka yang melakukan, yang memerintahkan untuk melakukan, dan yang berpartisipasi dalam melakukan perbuatan; (b) mereka yang dengan memberi atau menjanjikan sesuatu dengan menyalahgunakan kekuasaan atau martabat, dengan cara kekerasan, ancaman atau penyesatan, atau dengan memberi kesempatan, cara atau informasi, dengan sengaja mendorong orang lain untuk melakukan tindakan. (2) Terhadap penganjur, hanya perbuatan yang sengaja dianjurkan sajalah yang diperhitungkan, beserta akibat-akibatnya.

Pasal 149 (1) Barang siapa pada saat pemilihan umum berdasarkan peraturan umum, dengan memberi atau menjanjikan sesuatu, menyuap seseorang agar tidak menggunakan hak pilihnya atau menggunakan haknya dengan cara tertentu, diancam dengan pidana penjara selama-lamanya. sembilan bulan atau denda paling banyak empat ribu lima ratusan rupiah. (2) Hukuman yang sama diterapkan pada pemilih yang dengan menerima hadiah atau janji ingin disuap.

\section{SIMPULAN DAN SARAN}

\section{Simpulan}

Berdasarkan hasil analisis terhadap peraturan perundang-undangan atas permasalahan yang ada maka simpulan dari penelitian ini adalah: pertama, pengaturan larangan politik uang dalam Pilkada diatur dalam Undang- Undang Nomor 10 Tahun 2016 tentang Pilkada. Dalam peraturan tersebut diatur bahwa peserta politik, anggota partai politik, tim kampanye, relawan dan pihak- pihak lainnya yang terlibat dalam proses Pilkada dilarang untuk memberikan imbalan baik itu dalam bentuk uang atau materi lainnya. Setiap peserta dilarang untuk mempengaruhi pemilih untuk menggunakan hak pilihnya, menghalalkan berbagai cara untuk memperoleh suara dan dilarang untuk mempengaruhi pemilih untuk tidak memilih calon tertentu. Kedua, sanksi bagi calon peserta Pilkada yang melakukan politik uang akan dikenai sanksi pidana berupa kurungan minimal 36 bulan dan maksimal 72 bulan serta dikenai denda paling sedikit Rp. 200.000 .000 (dua ratus juta rupiah) dan paling banyak sebesar Rp. 1.000.000.000 (satu miliar rupiah).

\section{Saran}

Berdasarkan uraian kesimpulan tersebut maka saran yang dapat diberikan adalah: pertama, perlu adanya evaluasi terhadap regulasi mengenai Pilkada sehingga terdapat kejelasan bagi para calon peserta Pilkada terkait dengan hak-hak dan kewajiban yang harus dipenuhi. Keberadaan politik yang sebenarnya telah diatur, tetapi juga perlu diadakan evaluasi kembali agar lebih jelas dan menghindari terjadinya tafsir ganda pada aturan yang ada. Kedua, penegak hukum harus tegas menindak calon 
peserta yang tertangkap telah melakukan politik uang agar kedepannya tidak kembali terjadi kasus politik uang dalam Pilkada. Untuk menindak kasus pelanggaran harusnya tidak ada toleransi bagi peserta pemilu yang melakukan pelanggaran.

\section{DAFTAR PUSTAKA}

Aspinall, E., \& Sukmajati, M. (2015). Politik Uang Di Indonesia. Yogyakarta: PolGov.

Fajar, M., \& Achmad, Y. (2010). Dualisme Penelitian Hukum Empiris \& Hukum Normatif. Jakarta: Pustaka Pelajar.

Gaffar, A. (2004). Politik Indonesia: Transisi Menuju Demokrasi. Yogyakarta: Pustaka Pelajar. hariyani. (2015). Model Kampanye Pilkada Atasi Politik Uang dan Sikap Pesimis Pemilih (Telaah Teoritis dan Konsep Implementasinya). Jurnal Ilmiah Komunikasi, 6(1), 31-45.

Hertanto. (2006). Teori-Teori Poitik dan Pemikiran Politik di Indonesia. Bandar Lampung: Universitas Lampung.

Khairazi, F. (2015). Implementasi Demokrasi dan Hak Asasi Manusia di Indonesia. Jurnal Inovatif, $8(1), 72-94$.

Kumolo, T. (2015). Politik Hukum PILKADA Serentak. Bandung: PT. Mizan Publika.

Marsudi, K. E. R., \& Sunarso. (2019). Revitalisasi Pendidikan Politik melalui Pembentukan Kampung Anti Money Politic. JPPUMA Jurnal Ilmu Pemerintahan Dan Sosial Politik Universitas Medan Area, 7(2), 111.

Nabila, N., Prananingtyas, P., \& Azhar, M. (2020). Pengaruh Money Politic dalam Pemilihan Anggota Legislatif terhadap Keberlangsungan Demokrasi di Indonesia. Notarius, 13(1), 1-9.

Panjaitan, M. (2013). Logika Demokrasi Menyongsong Pemilihan Umum. Jakarta: Permata Aksara.

Seran, A. (2016). Demokrasi, Kedaulatan Rakyat, dan Pemilu. Respons, 21(1), 29-49. 